Archives of Agriculture and Environmental Science

\title{
Irrigation water quality assessment of Betagi Upazila under Barguna district in Bangladesh
} \author{
Islam $^{1^{*}}$ (D) and Mahbuba Ferdous ${ }^{1}$ \\ ${ }^{1}$ Department of Soil Science, Patuakhali Science and Technology University, Patuakhali, BANGLADESH \\ ${ }^{2}$ The United Graduate School of Agricultural Sciences, Kagoshima University, Kagoshima, JAPAN \\ ${ }^{3}$ Faculty of Agriculture, University of the Ryukyus, Okinawa 903-0213, JAPAN \\ *Corresponding author's E-mail: monirulpstu1@gmail.com
}

Tanjiba Akter ${ }^{1}$, Mohammad Kabirul Islam ${ }^{1,2,3}$, Majumder Md. Sagirul Islam ${ }^{2,3}$, Md. Monirul

\section{ARTICLE HISTORY}

Received: 13 September 2019

Revised received: 10 October 2019

Accepted: 16 November 2019

\section{Keywords}

Bangladesh

Barguna district

Groundwater

Irrigation

Surfacewater

Water quality

\begin{abstract}
Irrigation water quality is important for the successful crop production. The present study aimed to assess the quality of both ground and surface water for use of irrigation purposes at Betagi Upazila under Barguna district in Bangladesh. Forty two water samples were collected from different locations and their important chemical properties including $\mathrm{pH}, \mathrm{EC}$, the concentration of $\mathrm{PO}_{4}{ }^{3-}, \mathrm{SO}_{4}{ }^{2-}, \mathrm{K}^{+}$, and $\mathrm{Na}^{+}$were analyzed. Results revealed that the $\mathrm{pH}$ of the ground and surface water were ranged from 7.23 to 8.49 and 6.98 to 7.96 , respectively. Electrical conductivity (EC) of the water samples were 590 to $1950 \mu \mathrm{Scm}^{-1}$ and 110 to $380 \mu \mathrm{Scm}^{-1}$ respectively. The $\mathrm{PO}_{4}{ }^{3-}$ concentration in groundwater was 0.10 to $0.74 \mathrm{mgL}^{-1}$ and surface water was 0.05 to $0.20 \mathrm{mgL}^{-1}$. The $\mathrm{SO}_{4}{ }^{2-}$ concentration of groundwater ranged from 1.29 to $3.10 \mathrm{mgL}^{-1}$ and surfacewater was 2.11 to $7.28 \mathrm{mgL}^{-1}$. The $\mathrm{K}^{+}$ion concentration was 4.55 to $11.38 \mathrm{mgL}^{-1}$ in groundwater and 6.12 to $22.44 \mathrm{mgL}^{-1}$ in surface water. The $\mathrm{PO}_{4}{ }^{3-}$ and $\mathrm{SO}_{4}{ }^{2-}$ concentration in most of the ground and surface water samples within the "safe" limit for irrigation, whereas the $\mathrm{pH}, \mathrm{EC}$, and $\mathrm{K}^{+}$concentration in both ground and surface water were not in the safe limit. Besides this, $\mathrm{Na}^{+}$concentration was higher in groundwater than surface water. Based on chemical properties, surface water is more suitable as irrigation water compared to groundwater in the study area.
\end{abstract}

(C)2019 Agriculture and Environmental Science Academy

Citation of this article: Akter, T., Islam, M.K., Islam, M.M.S., Islam, M.M. and Ferdous, M. (2019). Irrigation water quality assessment of Betagi Upazila under Barguna district in Bangladesh. Archives of Agriculture and Environmental Science, 4(4): 428-433, https://dx.doi.org/10.26832/24566632.2019.040409

\section{INTRODUCTION}

Water, the vital element in all aspects of life in the world, plays a significant role regarding a person, socio-economic development and the existence of ecosystems (Goswami and Bisht, 2017). It is a fundamental part of humans, plants, animals, and other living organisms. The quality and quantity of any water supply organizing are highly important, especially when considering purposes. Irrigation water influences soil and crops, and their management. It is possible to be able to produce highquality crops only by using high-quality irrigation water sources when other inputs are optimal (Sarker et al., 2000). Normal water quality for irrigation will be a significant criterion for the prosperous crop production as this contains different toxic ions in varying concentrations. Irrigated agriculture is dependent on the water of useable quality. If inferior of normal water is employed for irrigation, poisonous aspects may accumulate in the soil thus showing signs of damage soil properties. In Bangladesh, a major part of cultivable land is under rainfed ecosystem (Goel et al., 2019). But the rainfall is not enough for the dry season. Therefore, farmers face an acute shortage of irrigation and drinking water during the dry season and use water from the two surface and underground sources. Besides agricultural point of view, the water of desirable quality is necessary for the drinking, domestic and industrial purposes. Thus, water quality assessment is most considerable for irrigation. 
The substance constituents of irrigation water can affect plant growth directly through toxicity or even deficiency, or indirectly by simply altering plant availability regarding nutrients (Kumar et al., 2019). The substance constituents of water determine its quality as well as its utilization about irrigation, industrial and domestic usages. All water includes a varying amount of different species of cations and anions. Among them, the primary soluble constituents are $\mathrm{Ca}^{2}+\mathrm{Mg}^{2+}, \mathrm{Na}^{+}$and $\mathrm{K}^{+}$as cations and $\mathrm{Cl}^{-}, \mathrm{SO}_{4}{ }^{2-}$ and $\mathrm{HCO}^{3-}, \mathrm{PO}_{4}{ }^{3-}$ as anions. From the soluble constituents, $\mathrm{Ca}^{2+}, \mathrm{Mg}^{2+}, \mathrm{Na}^{+}, \mathrm{Cl}^{-}, \mathrm{SO}_{4}{ }^{2-}, \mathrm{HCO}^{3-}$ and $\mathrm{B}^{+}$are regarding prime importance in judging the water quality regarding irrigation. Water contains specific potentially toxic ions such as $\mathrm{B}^{+}$, $\mathrm{Na}^{+}, \mathrm{Cl}^{-}$etc. (Kumar et al., 2018). The concentrations regarding these toxic ions in the irrigation water are extremely important because many crops are susceptible to even extremely low concentrations of these types of aspects (Hira et al., 2018). Irrigation water top quality is normally judged by the total salt concentration, comparative proportions of ions or even sodium adsorption ratio and the contents of $\mathrm{HCO}_{3}{ }^{-}$and $\mathrm{CO}_{3}{ }^{2-}$. For this specific reason, some important active agents of water are vital to evaluate its suitability for irrigations, drinking, livestock and business usages.

Within the southern area of Bangladesh, there are mainly three resources of irrigation water - surface water, rainwater, and groundwater. Owing to the effect of climate change, rainfall anomaly leads to the uncertainty of rainwater as a source of irrigation water. Moreover, monsoon rains usually are available for only several months (May to August). Surface water in the southern area of the region is exposed to seawater intrusion due to the continuous influence of high and low tides and the salinity is increasing daily due to the effect of climate change. During the monsoon, the salinity of surface drinking water decreases but in additional season's salinity remains largely determined by the geology regarding the area. This can make surface water unsuitable to be able to use as irrigation normal water all year round, especially in the dry season (November to
April). At that moment, groundwater is the only source to irrigate crops field.

Some organized investigations on the water quality in some selected sites regarding Bangladesh have been conducted; all chemical analyses of these investigations confined within $\mathrm{Ca}^{2+}$, $\mathrm{Mg}^{2+}, \mathrm{Na}^{+}, \mathrm{Cl}^{-}, \mathrm{SO}_{4}{ }^{2-}, \mathrm{HCO}^{3-}, \mathrm{Fe}^{2+}, \mathrm{B}^{+}$and $\mathrm{Na}^{+}$. But attention has not yet done on the water quality regarding Betagi Upazila, for this area was selected for the study. The total land area of Betagi Upazila under the district of Barguna is 64.77 square kilometers. There are usually seven (7) unions of the Betagi Upazila, which are the Bibichini, Betagi, Mokamia, Hosnabad, Buramazumdar, Kazirabad, Sarishamuri. The analysis area under the AEZ 18 (Young Meghna Estuarine Floodplain). In the study area surface water source (pond) is used for irrigation and groundwater (deep tube-well especially hand tube-well) can be used for drinking without judging chemical quality. Consequently, the objective of the present investigation was to evaluate the quality of surface and groundwater as well as their suitability for irrigation and drinking purposes.

\section{MATERIALS AND METHODS}

Water selections for quality assessment were analyzed for chemical matters. An effort has been obtained to analyze ground and surface water samples collected from the Betagi Upazila under the district regarding Barguna and the substance analyses are the determination of $\mathrm{pH}$, electrical conductivity (EC) and major ionic matters like $\mathrm{PO}_{4}{ }^{3}-, \mathrm{SO}_{4}{ }^{2}-, \mathrm{K}^{+}$, and $\mathrm{Na}^{+}$.

\section{Site selection}

Groundwater and surface water samples were collected from selected sites regarding Betagi Upazila. Forty-two (42) groundwater and surface water samples were collected from 7 unions. Twenty-one (21) groundwater samples and Twenty-one (21) surface water samples were collected in the course of the dry season from January 25 to December 28, 2016.

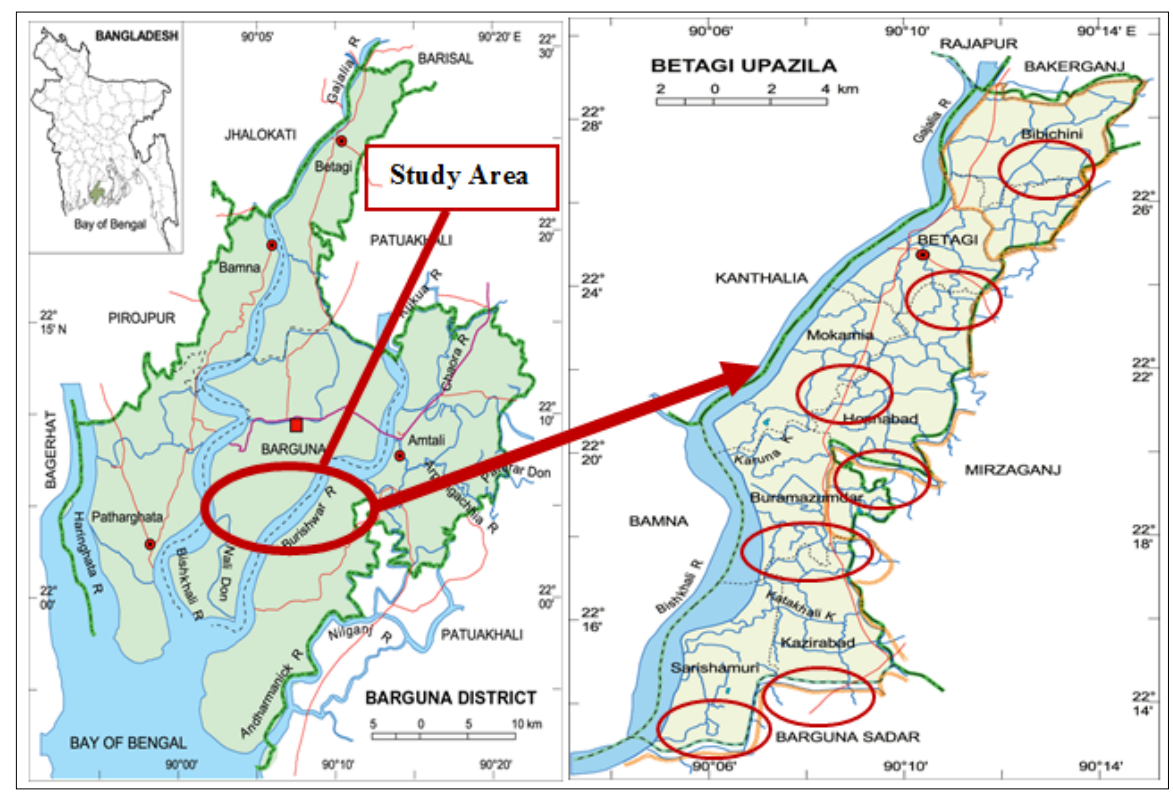

Figure 1. Map showing location of the experimental area. 
Methodology of sample collection and analysis

All analyses were done following the procedures mentioned by Hunt and Wilson (1986) and APHA (2012). The water samples were collected from both surface and underground sources (Figure 1). Water samples were collected in $500 \mathrm{ml}$ plastic bottles. These bottles were cleaned with dilute hydrochloric acid and then washed with tap water followed by distilled water. Before sampling, bottles were again rinsed 3 to 4 times with water to be sampled. The collected samples were tightly sealed immediately to avoid publicity to air. Samples were collected at the running condition of the hand tube well after the discharge of enough quantity of water. All water was colorless, air, tasteless and free from turbidity at the time of sampling. The water samples after proper marking and labeling were carried to the Central Laboratory, at Patuakhali Science and Technology University, for chemical substance analyses and were retained in a clean, cool and dry place. Samples were filtered through Whatman number I filter document to eliminate undesirable solid and suspended materials. The analyses were conducted within a few days'. The $\mathrm{pH}$ and EC are immediately taken while carried to the samples at the central lab of Patuakhali Science and Technological University. Water samples were protected against bacterial invasion either by adding two to three drops of pure toluene.

\section{Statistical analysis}

Statistical analysis of the data generated out of the chemical analysis of water samples was done with the help of a scientific calculator (Casio Super FX-100D) following the standard procedure as described by Gomez and Gomez (1984). Correlation studies also performed following the standard method of a computer program (SPSS).

\section{RESULTS AND DISCUSSION}

The $\mathrm{pH}, \mathrm{EC}$ and the ionic constituents such as $\mathrm{PO}_{4}{ }^{3-}, \mathrm{SO}_{4}{ }^{2-}, \mathrm{K}^{+}$, $\mathrm{Na}^{+}$in the water samples have been presented in the Tables 2 and 3. The salient features of the analyses have been discussed in the light of relevant research findings wherever applicable. The results have been discussed under the following headings.

\section{Ground and surface water rating for irrigation purposes}

$\mathrm{pH}$ : The $\mathrm{pH}$ of groundwater in the dry period ranged from 7.23 to 8.49 indicating the particular slightly alkaline in characteristics with the mean value of 8.00 (Table 2). The $\mathrm{pH}$ regarding 8 samples was below the mean value and the rest 13 samples were higher than the suggested value. The standard deviation of groundwater samples was 0.264 . The $\mathrm{pH}$ of surface water samples ranged from 6.98 to 7.96 in dry season indicating neutral to alkaline in characteristics with the mean value 7. 32 (Table 3). The $\mathrm{pH}$ of 13 samples was less than the mean value. The $\mathrm{pH}$ level of 8 samples was higher than the suggested value in the dry time of year. The standard deviation had been 0.260 in the dry season (Table 3). Amongst all the samples the highest $\mathrm{pH}$ value 8.49 was obtained in the sample no. MG 2 was hand tube well water, collected from Mokamia union, Mokamia bazar and the lowest value 6.98 had been obtained in the sample no. BS 3 it had been pond water, collected from Bibichini Union, adjacent pond. (Fipps, 2003) reported of which the suitable $\mathrm{pH}$ range for irrigation water 6.0 to 8.5. Based on this limit, both the groundwater and surface water of the study area were suitable for irrigation.

Electrical conductivity (EC): The electrical conductivity regarding groundwater samples in dry season ranged from 590 to $1950 \mu \mathrm{Scm}^{-1}$ with the mean value of $1068.57 \mu \mathrm{Scm}^{-1}$ (Table 2). The EC value of 13 samples was below the mean value, and the rest 8 samples were higher than the mean value. The standard deviation of groundwater samples was 429.17 (Table 2). The EC value of surface water samples ranged from 110 to be able to $380 \mu \mathrm{Scm}^{-1}$ with all the mean value $210.95 \mu \mathrm{Scm}^{-1}$ (Table 3). The EC value of 10 samples was higher than the mean value, in addition to the rest of the 11 samples have been lower than the mean value. The standard deviation was 75.13 in the dry season (Table 3). The groundwater regarding the study area showed higher EC value as compared to surface water. Among all the water samples the highest EC value $1950 \mu \mathrm{Scm}^{-1}$ was obtained in typically the sample no. BeG 1 had been Hand tube well water sample, collected from a hand tube well adjacent Betagi college regarding Betagi union and the lowest value $110 \mu \mathrm{Scm}^{-1}$ was obtained in the sample no. BS 1 had been Pond water collected from Bibichini union, Khashpukur par, sample no. BeS 2 was pond water collected from Betagi Bus Stand, sample no. KS 1 was pond water collected from Kazirabad union, Kaonia. According to (Islam and Shamsad, 2009) the groundwater in the research area was found "permissible" class and surface water was of "good" class.

\section{Ionic constituents}

The ionic constituents like $\mathrm{PO}_{4}{ }^{3-}, \mathrm{SO}_{4}{ }^{2-}, \mathrm{K}^{+}, \mathrm{Na}^{+}$of the water samples were analyzed. The ion present in all samples in relation to irrigation water quality have been discussed as follows:

Phosphate $\left(\mathrm{PO}_{4}{ }^{3-}\right)$ : The phosphate concentration of groundwater samples in dry season ranged from 0.10 to $0.74 \mathrm{mgL}^{-1}$ with mean value with $0.32 \mathrm{mgL}^{-1}$ (Table 2). The $\mathrm{PO}_{4}{ }^{3-}$ concentration of 11 samples were lower than the mean value, the rest 10 samples were higher than the mean value. The standard deviation was 0.169 (Table 2). The $\mathrm{PO}_{4}{ }^{3-}$ concentration of surface water samples ranged from 0.05 to $0.20 \mathrm{mgL}^{-1}$ in dry period with the mean value of $0.08 \mathrm{mgL}^{-1}$ (Table 3). The $\mathrm{PO}_{4}{ }^{3-}$ concentration of 4 samples was higher than the mean value, the rest 16 samples were lower than the mean value and one sample has been equal to the mean value. The standard deviation was 0.0362 (Table 3).

Sulphate $\left(\mathrm{SO}_{4}{ }^{2-}\right)$ : The concentration of sulphate of groundwater samples in dry season ranged from 1.29 to $3.10 \mathrm{mgL}^{-1}$ with the mean value of $1.99 \mathrm{mgL}^{-1}$ (Table 2). The $\mathrm{SO}_{4}{ }^{2-}$ concentration of 12 samples were lower than the mean value, and the rest 9 
Table 1. Detail information regarding surface and groundwater sources of Betagi Upazila under Barguna District in Bangladesh.

\begin{tabular}{|c|c|c|c|c|c|}
\hline \multirow{2}{*}{$\begin{array}{l}\text { Sample } \\
\text { number }\end{array}$} & \multicolumn{2}{|c|}{ Sampling location } & \multirow{2}{*}{ Sources } & \multirow{2}{*}{ Depth (ft.) } & \multirow{2}{*}{ Season } \\
\hline & Union & Village & & & \\
\hline BS 1 & & Khashpukur par & PW & - & \\
\hline BS 2 & Bibichini & Bibichini Bazar & PW & - & Dry season \\
\hline BS 3 & & Fultola & PW & - & \\
\hline BG 1 & & Bibichini Bazar & HTW & 550 & \\
\hline BG 2 & Bibichini & Fultola & HTW & 760 & Dry season \\
\hline BG 3 & & Bibichini Bazar & HTW & 850 & \\
\hline $\operatorname{BeS} 1$ & & Betagi Bazar & PW & - & \\
\hline BeS 2 & Betagi & Betagi Bus Stand & PW & - & Dry season \\
\hline BeS 3 & & Betagi College & PW & - & \\
\hline $\mathrm{BeG} 1$ & & Betagi College & HTW & 1250 & \\
\hline $\mathrm{BeG} 2$ & Betagi & Betagi Bazar & HTW & 1200 & Dry season \\
\hline BeG 3 & & Betagi Bus Stand & HTW & 1000 & \\
\hline MS 1 & & Mokamia Madrasha & PW & - & \\
\hline MS 2 & Mokamia & Karuna & PW & - & Dry season \\
\hline MS 3 & & Mokamia Bazar & PW & - & \\
\hline MG 1 & & Karuna & HTW & 1200 & \\
\hline MG 2 & Mokamia & Mokamia Bazar & HTW & 1000 & Dry season \\
\hline MG 3 & & Mokamia Madrasha & HTW & 1000 & \\
\hline HS 1 & & Hosnabad Bazar & PW & - & \\
\hline HS 2 & Hosnabad & Jailsha & PW & - & Dry season \\
\hline HS 3 & & Jailsha & PW & - & \\
\hline HG 1 & & Jailsha & HTW & 1250 & \\
\hline HG 2 & Hosnabad & Hosnabad Bazar & HTW & 1000 & Dry season \\
\hline HG 3 & & Jailsha & HTW & 1000 & \\
\hline BUS 1 & & Kajirhat Bazar & PW & - & \\
\hline BUS 2 & Buramazumdar & Kajirhat School & PW & - & Dry season \\
\hline BUS 3 & & Kajirhat & PW & - & \\
\hline BUG 1 & & Kajirhat & HTW & 800 & \\
\hline BUG 2 & Buramazumdar & Kajirhat School & HTW & 850 & Dry season \\
\hline BUG 3 & & Kajirhat Bazar & HTW & 1000 & \\
\hline KS 1 & & Kaonia & PW & - & \\
\hline KS 2 & Kazirabad & Kaonia School & PW & - & Dry season \\
\hline KS 3 & & Kaonia Mosjid & PW & - & \\
\hline KG 1 & & Kaonia Mosjid & HTW & 1000 & \\
\hline KG 2 & Kazirabad & Kaonia School & HTW & 850 & Dry season \\
\hline KG 3 & & Kaonia & HTW & 750 & \\
\hline SS 1 & & Sarishamuri Bazar & PW & - & \\
\hline SS 2 & Sarishamuri & Sarishamuri Bazar & PW & - & Dry season \\
\hline SS 3 & & Talukder Bari & PW & - & \\
\hline SG 1 & & Molla Bari & HTW & 1250 & \\
\hline SG 2 & Sarishamuri & Talukder Bari & HTW & 950 & Dry season \\
\hline SG 3 & & Sarishamuri Bazar & HTW & 850 & \\
\hline
\end{tabular}

$\mathrm{HTW}=$ Hand tube well water; $\mathrm{BG}=$ Bibichini ground water; $\mathrm{HG}=$ Hosnabad ground water; $\mathrm{BeG}=\mathrm{Betagi}$ ground water; $\mathrm{MG}=\mathrm{Mokamia}$ ground water; $\mathrm{BuG}=$ Buramazumder ground water; $\mathrm{KG}=$ Kazirabad ground Water; $\mathrm{SG}=$ Sarishamuri ground water.

samples were higher than the mean value. The standard deviation was 0.525 (Table 2). The $\mathrm{SO}_{4}{ }^{2-}$ concentration of surface water samples ranged from 2.11 to $7.28 \mathrm{mgL}^{-1}$ in the dry season with the mean value regarding $3.96 \mathrm{mgL}^{-1}$ (Table 3). The $\mathrm{SO}_{4}{ }^{2-}$ concentration of 12 samples have been lower than the mean value, and rest samples were higher than the mean value. The standard deviation was 1.55 (Table 3).

Potassium $\left(\mathrm{K}^{+}\right)$: The potassium concentration of groundwater in dry season ranged from 4.55 to $11.38 \mathrm{mgL}^{-1}$ with the mean value of $7.45 \mathrm{mgL}^{-1}$ (Table 2). The $\mathrm{K}^{+}$concentration of (10) ten samples was higher than the mean value and rest 10 samples were lower than the mean value and one sample have been equal the standard deviation was 2.18 (Table 2 ). The $\mathrm{K}^{+}$concentration of surface water samples ranged from 6.12 in order to $22.44 \mathrm{mgL}^{-1}$ in the dry season with the mean value of $9.68 \mathrm{mgL}^{-1}$ (Table 3 ). The $\mathrm{K}^{+}$concentration of seven (7) samples was higher than the mean value and the rest 14 samples were lower than the mean value. The standard deviation was 3.87 (Table 3). The surface water contained a larger quantity of $\mathrm{K}^{+}$than the groundwater. Among all the water samples the lowest value of $\mathrm{K}^{+} 4.55$ $\mathrm{mgL}^{-1}$, was seen in the sample no. SG 2 was Hand tube well water, collected from Sarishamuri union, Talukder bari adjacent hand tube well and the highest value of $\mathrm{K}^{+} 22.44 \mathrm{mgL}^{-1}$ was observed in the sample no. HS 3 it was Pond water, collected from Hosnabad union, Jailsha. The presence of better quantity 
Table 2. $\mathrm{pH}, \mathrm{EC}$, and concentration of $\mathrm{PO}_{4}{ }^{3-}, \mathrm{SO}_{4}{ }^{2-}, \mathrm{K}^{+}$, and $\mathrm{Na}^{+}$in groundwater collected in the dry season.

\begin{tabular}{|c|c|c|c|c|c|c|c|}
\hline $\begin{array}{l}\text { Sample } \\
\text { number }\end{array}$ & $\begin{array}{l}\text { Sources } \\
\text { of water }\end{array}$ & $\mathrm{pH}$ & $\mathrm{EC}\left(\mu \mathrm{Scm}^{-1}\right)$ & $\mathrm{PO}_{4}{ }^{3-}\left(\mathrm{mg} \mathrm{L}^{-1}\right)$ & $\mathrm{SO}_{4}{ }^{2-}\left(\mathrm{mg} \mathrm{L}^{-1}\right)$ & $\mathrm{K}^{+}\left(\mathrm{mg} \mathrm{L}^{-1}\right)$ & $\mathrm{Na}^{+}\left(\mathrm{mg} \mathrm{L}^{-1}\right)$ \\
\hline BG 1 & HTW & 7.48 & 1020 & 0.42 & 2.34 & 8.13 & 52.71 \\
\hline BG 2 & & 8.01 & 1050 & 0.35 & 1.73 & 6.80 & 50.57 \\
\hline BG 3 & & 8.07 & 910 & 025 & 1.81 & 5.82 & 54.68 \\
\hline BeG 1 & & 7.72 & 1950 & 0.13 & 1.58 & 11.38 & 57.96 \\
\hline $\mathrm{BeG} 2$ & & 7.91 & 1590 & 0.17 & 1.61 & 9.08 & 64.37 \\
\hline BeG 3 & & 7.94 & 1720 & 0.16 & 1.61 & 10.09 & 60.43 \\
\hline MG 1 & & 8.10 & 1540 & 0.17 & 1.29 & 8.40 & 66.34 \\
\hline MG 2 & & 7.91 & 1630 & 0.18 & 1.40 & 11.09 & 54.52 \\
\hline MG 3 & & 7.96 & 1390 & 0.21 & 1.58 & 8.43 & 65.02 \\
\hline HG 1 & & 8.08 & 960 & 0.15 & 1.58 & 5.65 & 56.49 \\
\hline HG 2 & & 8.05 & 1250 & 0.23 & 1.35 & 7.51 & 61.74 \\
\hline HG 3 & & 7.23 & 1310 & 0.10 & 1.67 & 7.84 & 63.22 \\
\hline BuG 1 & & 7.98 & 610 & 0.55 & 2.54 & 5.41 & 48.11 \\
\hline BuG 2 & & 8.03 & 690 & 0.53 & 1.78 & 5.38 & 51.56 \\
\hline BuG 3 & HTW & 8.07 & 630 & 0.44 & 2.28 & 11.32 & 51.23 \\
\hline KG 1 & & 8.20 & 730 & 0.36 & 2.25 & 5.06 & 52.87 \\
\hline KG 2 & & 8.49 & 610 & 0.40 & 2.51 & 5.68 & 47.29 \\
\hline KG 3 & & 8.13 & 910 & 0.28 & 2.84 & 5.03 & 58.62 \\
\hline SG 1 & & 8.31 & 720 & 0.51 & 2.31 & 7.45 & 42.86 \\
\hline SG 2 & & 8.19 & 630 & 0.42 & 2.54 & 4.55 & 52.05 \\
\hline SG 3 & & 8.17 & 590 & 0.74 & 3.10 & 6.24 & 48.60 \\
\hline Range & & $7.23-8.49$ & 590-1950 & $0.10-0.74$ & $1.29-3.10$ & $4.55-11.38$ & $42.86-66.34$ \\
\hline Mean $(n=24)$ & & 8.00 & 1068.57 & 0.32 & 1.99 & 7.45 & 55.30 \\
\hline $\mathrm{Sd}( \pm)$ & & 0.264 & 429.17 & 0.17 & 0.525 & 2.18 & 6.49 \\
\hline
\end{tabular}

$\mathrm{HTW}=$ Hand tube well water; $\mathrm{BG}=$ Bibichini ground water; $\mathrm{HG}=$ Hosnabad ground water; $\mathrm{BeG}=$ Betagi ground water; $\mathrm{MG}=\mathrm{Mokamia}$ ground water; BuG= Buramazumder Ground water; KG= Kazirabad ground water; $\mathrm{SG}=$ Sarishamuri ground water.

Table 3. $\mathrm{pH}, \mathrm{EC}$, and concentration of $\mathrm{PO}_{4}{ }^{3-}, \mathrm{SO}_{4}{ }^{2-}, \mathrm{K}^{+}$, and $\mathrm{Na}^{+}$of surface water collected in the dry season.

\begin{tabular}{|c|c|c|c|c|c|c|c|}
\hline $\begin{array}{l}\text { Sample } \\
\text { number }\end{array}$ & $\begin{array}{l}\text { Sources of } \\
\text { water }\end{array}$ & $\mathrm{pH}$ & $\mathrm{EC}\left(\mu \mathrm{Scm}^{-1}\right)$ & $\mathrm{PO}_{4}{ }^{3-}\left(\mathrm{mg} \mathrm{L}^{-1}\right)$ & $\mathrm{SO}_{4}{ }^{2-}\left(\mathrm{mg} \mathrm{L}^{-1}\right)$ & $\mathrm{K}^{+}\left(\mathrm{mg} \mathrm{L}^{-1}\right)$ & $\mathrm{Na}^{+}\left(\mathrm{mg} \mathrm{L}^{-1}\right)$ \\
\hline BS 1 & PW & 7.37 & 110 & 0.07 & 2.13 & 6.39 & 9.03 \\
\hline BS 2 & & 7.57 & 240 & 0.07 & 4.97 & 6.12 & 10.02 \\
\hline BS 3 & & 6.98 & 120 & 0.05 & 2.11 & 6.71 & 6.73 \\
\hline $\mathrm{BeS} 1$ & & 7.06 & 220 & 0.05 & 4.36 & 6.59 & 11.17 \\
\hline Bes 2 & & 7.20 & 110 & 0.06 & 3.92 & 8.28 & 10.18 \\
\hline $\mathrm{BeS} 3$ & & 7.96 & 270 & 0.06 & 5.26 & 8.81 & 15.93 \\
\hline MS 1 & & 7.06 & 240 & 0.10 & 2.16 & 11.03 & 12.48 \\
\hline MS 2 & & 7.51 & 290 & 0.05 & 2.81 & 11.21 & 12.97 \\
\hline MS 3 & & 7.64 & 380 & 0.08 & 7.28 & 11.32 & 17.57 \\
\hline HS 1 & & 7.24 & 200 & 0.07 & 6.58 & 8.66 & 11.33 \\
\hline HS 2 & & 7.22 & 220 & 0.06 & 5.00 & 6.15 & 14.12 \\
\hline HS 3 & & 7.64 & 380 & 0.20 & 2.75 & 22.44 & 11.33 \\
\hline BuS 1 & & 7.29 & 220 & 0.06 & 2.75 & 9.52 & 14.12 \\
\hline BuS 2 & & 7.03 & 220 & 0.09 & 6.20 & 8.93 & 11.66 \\
\hline BuS 3 & & 7.23 & 180 & 0.08 & 5.47 & 7.75 & 12.48 \\
\hline KS 1 & & 7.71 & 110 & 0.06 & 2.51 & 7.63 & 8.21 \\
\hline KS 2 & $C W$ & 7.13 & 170 & 0.05 & 3.19 & 7.24 & 14.61 \\
\hline SS 1 & PW & 7.06 & 190 & 0.07 & 3.13 & 10.47 & 11.66 \\
\hline SS 2 & $\mathrm{CW}$ & 7.34 & 170 & 0.08 & 3.10 & 15.61 & 12.15 \\
\hline SS 3 & PW & 7.23 & 190 & 0.16 & 3.48 & 14.10 & 8.54 \\
\hline \multicolumn{2}{|l|}{ Range } & $6.98-7.96$ & $110-380$ & $0.05-0.20$ & $2.11-7.28$ & $6.12-22.44$ & $6.73-17.57$ \\
\hline \multicolumn{2}{|c|}{ Mean $(n=26)$} & 7.32 & 210.95 & 0.08 & 3.96 & 9.68 & 11.67 \\
\hline \multicolumn{2}{|l|}{$\mathrm{Sd}( \pm)$} & 0.260 & 75.13 & 0.0362 & 1.55 & 3.87 & 2.68 \\
\hline
\end{tabular}

$\mathrm{HTW}=$ Hand tube well water; $\mathrm{BG}=$ Bibichini ground water; $\mathrm{HG}=$ Hosnabad ground water; $\mathrm{BeG}=$ Betagi ground water; $\mathrm{MG}=\mathrm{Mokamia}$ ground water; $\mathrm{BuG}=$ Buramazumder ground water; $\mathrm{KG}=$ Kazirabad ground water; $\mathrm{SG}=$ Sarishamuri ground water. 
of $\mathrm{K}^{+}$in some groundwater samples could be as a result of some potash bearing minerals just like sylvite $(\mathrm{KCl})$ and niter $\left(\mathrm{KNO}_{3}\right)$ in aquifers (El-Gohary, 2011) reported that seas containing less than $2 \mathrm{mgL}^{-1} \mathrm{~K}^{+}$are well suited for irrigation. In accordance with this limit, both the ground and surface waters from the study area were unsuitable for irrigation.

Sodium $\left(\mathrm{Na}^{+}\right)$: The sodium concentration of groundwater samples in dry season ranged from 42.86 to $66.34 \mathrm{mgL}^{-1}$ with the mean value 55.30 (Table 2). The $\mathrm{Na}^{+}$concentration of 9 samples was higher than the mean value and the rest 12 samples were lower than the mean value. The standard deviation was 6.49 (Table 2). The sodium concentration regarding the surface water samples ranged from 6.73 to $17.57 \mathrm{mgL}^{-1}$ with the mean value of $11.67 \mathrm{mgL}^{-1}$ (Table 3). The sodium concentration of 9 samples was higher than the mean value and rest twelve (12) samples were lower than the mean value. The standard deviation was 2.68 (Table 3). The groundwater study was higher $\mathrm{Na}^{+}$content than the surface water. Among all the samples, the highest value of $\mathrm{Na}^{+} 66.344 \mathrm{mg} \mathrm{L}^{-1}$ was observed in the sample no. MG 1 was Hand tube well-drinking water, collected from Mokamia union, Karuna adjacent road and the lowest value of $\mathrm{Na}^{+} 6.73 \mathrm{mgL}^{-1}$ had been noticed in the sample no. BS 3 it was pond water collected through Bibichini union, Shikder bari adjacent pond. Tester and Davenport (2003) proposed that water containing less than to $40 \mathrm{mgL}^{-1} \mathrm{Na}^{+}$had been well suited for irrigation of crop plants. Based on $\mathrm{Na}^{+}$content, all the collected surface water of the study area can safely be used for irrigation of crops but groundwater was unsuitable for irrigation goals.

\section{Conclusion}

From the above results, it has been concluded that $\mathrm{PO}_{4}{ }^{3-}$ and $\mathrm{SO}_{4}{ }^{2-}$ in both ground and surface water in the study area were within the "safe" limit for irrigation. The $\mathrm{pH}, \mathrm{EC}$ and $\mathrm{K}^{+}$concentration in both ground and surface water were not in the safe limit. Besides these, $\mathrm{Na}^{+}$concentration was higher in groundwater than surface water. Based on the chemical properties, surface water is more suitable as irrigation water compared to groundwater in the study area.

\section{ACKNOWLEDGEMENTS}

The authors are thankful to the Professor Dr. Md. Fazlul Haque, Chairman, Department of Soil Science, Patuakhali Science and
Technology University, Dumki, Patuakhali-8602, Bangladesh for his valuable suggestions and cordial cooperation.

Open Access: This is an open access article published under the terms and conditions of Creative Commons AttributionNonCommercial 4.0 International License which permits noncommercial use, distribution, and reproduction in any medium, provided the original author(s) if the sources are credited.

\section{REFERENCES}

APHA (2012). Standard Methods for the Reanimation of Water and Waste Water 19th edn. Published by American Water Works Association (AWWA) \&Water Environmental Federation (AWWA).pp. 1-55.

El-Gohary, M. (2011). Chemical deterioration of egyptian limestone affected by saline water. International Journal of Conservation Science, 2(1): 1-10.

Fipps, G. (2003). Irrigation water quality standards and salinity management strategies. Texas A\&M Agrilife Extension, 4(03): 1-18.

Gomez, K.A. and Gomez, A.A. (1984). Statistical Procedures for Agricultural Research. 2nd edn. An International Rice Research Institute Book. A WileyInterscience publication, New York. pp. 442-443.

Goswami, K.B. and Bisht, P.S. (2017). The role of water resources in socioeconomic development. International Journal for Research in Applied Science \& Engineering Technology, 887(12): 2321-9653.

Goel, V., Islam, M.S., Yunus, M., Ali, M.T., Khan, A. F., Alam, N. and Emch, M. (2019). Deep tubewell microbial water quality and access in arsenic mitigation programs in rural Bangladesh. Science of The Total Environment, 659: 1577 1584.

Hira, T.A., Islam, M.K., Lipi, N.J., Islam, M.M., Bhuyan, M.I. and Ferdous, M. (2018). Assessment of ground and surface water quality for irrigation at Dumki, Patuakhali in Bangladesh. Journal of Chemical, Environmental and Biological Engineering, 2(2): 74-81, https://doi.org/10.11648/j.jcebe.20180202.16.

Hunt, D.T.E. and Wilson, A.L. (1986). The Chemical Analysis of Water-General Principles and Techniques, 2nd edn. The Royal Society of Chemistry, Cambridge, pp. 29-43.

Islam, M.S. and Shamsad, S.Z.K.M. (2009). Assessment of irrigation water quality of Bogra district in Bangladesh. Bangladesh Journal of Agricultural Research, 34 (4): 507-608.

Kumar, V., Kumar, P. and Singh, J. (2019). An introduction to contaminants in agriculture and environment. In: Kumar, V., Kumar, R., Singh, J. and Kumar, P. (eds) Contaminants in Agriculture and Environment: Health Risks and Remediation, Volume 1, Agro Environ Media, Haridwar, India, pp. 1-8, https://doi.org/10.26832/AESA-2019-CAE-0159-01

Kumar, V., Kumar, S., Srivastava, S., Singh, J. and Kumar, P. (2018). Water quality of River Ganga with reference to physico-chemical and microbiological characteristics during Kanwar Mela 2017, at Haridwar, India: A case study. Archives of Agriculture and Environmental Science, 3(1): 58-63.

Sarker, B.C., Hara, M. and Zaman, M.W. (2000). Suitability assessment of natural water in relation to irrigation and soil properties. Soil Science and Plant Nutrition, 46(4): 773-786. https://doi.org/10.1080/00380768.2000.10409143

Tester, M. and Davenport, R. (2003). $\mathrm{Na}^{+}$tolerance and $\mathrm{Na}^{+}$ transport in higher plants. Annals of Botany, 91(5): 503-527. https://doi.org/10.1093/aob/mcg058 